\title{
Interactive and interactional meta-discourse markers in conclusion sections of English master theses
}

\author{
Rezaei Zadeh, Zahra $\$ \\ English Department, Najafabad Branch, Islamic Azad University, Najafabad, Iran (zrzc2@yahoo.com) \\ Baharlooei, Roya \\ English Department, Najafabad Branch, Islamic Azad University, Najafabad, Iran \\ (royabaharlooie@yahoo.com) \\ Simin, Shahla \\ English Department, Najafabad Branch, Islamic Azad University, Najafabad, Iran (shahlasimin@yahoo.com)
}

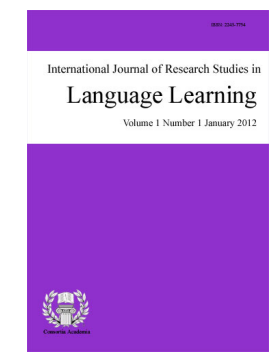

ISSN: 2243-7754 Online ISSN: 2243-7762

OPEN ACCESS

$\begin{array}{lll}\text { Received: } 17 \text { January } 2015 & \text { Revised: } 5 \text { February } 2015 & \text { Accepted: } 15 \text { February } 2015\end{array}$

\section{Abstract}

This study was conducted to compare the interactive and interactional meta-discourse markers in conclusion sections of English Teaching, English Translation, and English Literature Master Theses to find out if there are significant differences among conclusion sections of these Master Theses in terms of the frequency and types of interactive and interactional meta-discourse markers. To this end, 30 Master Theses of English Translation, English Teaching, and English Literature (10 from each) were selected randomly from library of Isfahan University, Islamic Azad university of Arak, and Islamic Azad university of Najaf Abad. Conclusion sections of these theses were written and stored in folders of Teaching, Translation, and Literature in computer. These were followed by analyzing the frequency and types of interactive and interactional meta-discourse markers in each section-in accordance with Hyland (2005) Taxonomy. In Descriptive analysis, the results show that Interactional Markers among these disciplines were employed more than Interactive ones. Interactional Markers were used considerably more in English Translation than in English Teaching and English Literature. Transitions were applied more than other interactive markers. Moreover, the findings indicate that there are significant differences among these disciplines considering use of interactive and interactional markers. The results of the present study might offer pedagogical implication of this aspect of meta-discourse for Assistant professors, Master candidates of Applied Linguistics to consider these markers in Master Theses more efficiently.

Keywords: meta-discourse; interactive markers; interactional markers; masteral thesis; taxonomy 


\section{Interactive and interactional meta-discourse markers in conclusion sections of English master theses}

\section{Introduction}

In Webster New Collegiate dictionary (2013), thesis is defined as a proposition that a person advances and offers to maintain by argument. This definition has three key elements:

A thesis is a proposition: it advances an idea, a hypothesis or a recommendation;

$>$ A thesis offers an argument: it presents a rationale for accepting the proposition made, rather than simply asserting a point of view; and

$>\quad$ The argument of the thesis should be maintained: it should be made convincingly by appropriate logic and sufficient evidence.

The most significant piece of writing that any student will ever do, a formidable task of intimidating length and exacting expectations which represents what is potentially achievable by individuals writing in a language that is not their own, therefore, the $\mathrm{PhD}$ and Master dissertations are considered to be significant for the advanced university students (Hyland, 2004).William (1981), elaborates meta-discourse as devices to help explain essays, to guide readers response to structure text. VandeKopple (1985), in his article "discourse about discourse" remarks that " meta-discourse is the way of talking or writing about a specialized topic common to a specific discourse community that allows such a community to engage in a level meaningful information exchange, and communicate beyond that which a generic type of discourse would allow"(p. 83).

VandeKopple(1985), categorized meta-discourse into two general group of textual and interpersonal. The textual categories are connectives which list words writers use to strengthen cohesion and code glosses which define unfamiliar words. William( 1989),proposed meta-discourse as helping writers to explain, show, argue, describe, suggest, contrast, add, expand, and summarize. Another William definition is as follows:

D Meta-discourse is used to express the logical connection, e.g., infer, support, prove, illustrate, therefore, in conclusion, however, and on the other hand.

$>$ In meta-discourse, the degree of certainty is hedged by writing for example, it seem that, perhaps, and I believe, probably.

$>\quad$ In meta-discourse, the intentions are announced or rewritten by using the first person pronouns; e.g.., we can say that, I have shown that, etc. (Williams 1989).

Crismore and Farnworth (1990), state that "meta-discourse is one way that writers make texts say what they are doing". They distinguish between attitudinal and informational matadicourse. The former includes features such as hedging and evaluation, the latter refers to language which serves to direct readers in how to understand the primary discourse message by referring, for example, to its text structure and content and to the author discourse actions, purposes or goals. Crismore, Markkanen and Steffensen (1993), and Valero-Garces(1996), state that "meta-discourse is the characteristics of a range of languages and genres, and has been used to investigate rhetorical differences in the texts written by different cultural groups" (p. 40).

Hyland (1998), remarks meta-discourse as an important means to facilitate communication, support a writer's position, and build a writer-reader relationship. Hyland (1998) separate meta-discourse into the textual and interpersonal categories. In textual meta-discourse, author uses these features to organize the propositional information in ways that will be coherent for a particular audience and appropriate for a given purpose. In interpersonal meta-discourse, writers use these features to indicate their attitude toward the information in the text or toward the readers.

While, Hyland (2000) describes meta-discourse as the linguistic resources applied to organize a discourse or the writer stand based on its content. Hyland and Tse (2004), explain meta-discourse as a self-reflective linguistic practice which evolves text and aware writers of reader imagination of that text. They also viewed writing as 
social engagement and disclose how writers of different disciplines position themselves within their discourse to signal their attitude towards propositional content and audience. According to Halliday (1978), the textual function refers to the function that language has the text creation, context relation to the situation and the preceding text. Linguistics, such as Enkvist (1975), and Mauranen (1993), follow Halliday textual meta-function, but other scholars, as VandeKopple (1985), Crismore and Farnsworth (1990), and Hyland (1988), cover not only text-organizing elements, but also interactive elements, such as the expressions of the author attitude and certainty. Crismore and Farnworth (1990), extend VandeKopple Taxonomy by consisting interactive elements.

In opposing with writers such as Crismore (1993), VandeKopple (1985), and Williams (1981), Hyland (2004), who offer textual features which are contributing towards either prepositional or interpersonal features, in addition, writers such as, Mauranen (1993), and Bunton (1999), who investigate meta-texts as the writers self-awareness of the unfolding text as discourse: how writers situate their language use to cover a text, a writer, and a reader; meta-discourse is signified as the writers reference to the text, the writer, or the reader and it also empowers analysts to see how the writers chooses to manage interpretive processes. Thompson (2001) defined interactive and interactional terms as the writer management of the information to guide readers through the text, and interactional as to refer to his or her explicit interactions to evaluate materials. Whereas, Hyland (2005) also represents an interpersonal model of meta-discourse, which views two broad categories: interactive (e.g., transition, frame markers, endophoric markers, evidential, code glosses) and interactional (e.g., hedges, boosters, attitude markers, self-mentions, engagement markers). These categories elaborate more on following table:

Table 1

Interpersonal Model of Hyland (2005)

\begin{tabular}{|c|c|c|}
\hline Category & Function & Examples \\
\hline Interactive & $\begin{array}{l}\text { Help to guide the reader } \\
\text { through the text }\end{array}$ & Resources \\
\hline Transitions & $\begin{array}{l}\text { Express relation between } \\
\text { main clauses }\end{array}$ & In addition; but; thus; and \\
\hline Frame markers & $\begin{array}{l}\text { Refers to discourse acts, } \\
\text { sequences, or stages }\end{array}$ & $\begin{array}{l}\text { Finally, to conclude, my } \\
\text { purpose is }\end{array}$ \\
\hline Endophoric markers & $\begin{array}{l}\text { Refer to information in other } \\
\text { parts of the text }\end{array}$ & $\begin{array}{l}\text { Noted above, see figure, in } \\
\text { section } 2\end{array}$ \\
\hline Evidential & $\begin{array}{l}\text { Refer to information from } \\
\text { other text }\end{array}$ & According to $\mathrm{X}, \mathrm{Z}$ states \\
\hline Code glosses & $\begin{array}{l}\text { Elaborate propositional } \\
\text { meanings }\end{array}$ & $\begin{array}{l}\text { Namely, e.g., such as, in } \\
\text { other words }\end{array}$ \\
\hline Interactional & $\begin{array}{l}\text { Involve the reader in the } \\
\text { text }\end{array}$ & Resources \\
\hline Boosters & $\begin{array}{l}\text { Emphasize certainty or } \\
\text { close dialogue }\end{array}$ & $\begin{array}{l}\text { About, in fact, definitely, it } \\
\text { is clear that }\end{array}$ \\
\hline Attitude markers & $\begin{array}{l}\text { Express writers attitude to } \\
\text { proposition }\end{array}$ & $\begin{array}{l}\text { Unfortunately, I agree, } \\
\text { surprisingly }\end{array}$ \\
\hline Self-mention & Explicit reference to author & I, me, my, our \\
\hline Hedges & $\begin{array}{l}\text { Withhold commitment and } \\
\text { open dialogue }\end{array}$ & Might, perhaps, possible \\
\hline Engagement markers & $\begin{array}{l}\text { Explicitly build relationship } \\
\text { with reader }\end{array}$ & $\begin{array}{l}\text { Consider, note, you can see } \\
\text { that }\end{array}$ \\
\hline
\end{tabular}

\section{Review of Literature}

Many scholars did investigation regarding use of meta-discourse markers in different genres such as books, articles, newspapers, research papers among different languages and disciplines. Intaraprawat and Steffensen (1995) analyzed meta-discourse markers in ESL university students' essays. In this paper, half of the essays received good ratings and half received poor ratings. The number of words, number of $\mathrm{T}$ units, and density of 
meta-discourse features were found in these essays. They concluded that good essays have greater variety of meta-discourse features within each category than the poor essays. In another study, Amiri (2001), investigates the impact of the use of meta-discourse on the improvement of Iranian EFL learners writing skill. In this research, 60 university students who were included in experimental group were taught the meta-discourse markers and functions. The results show that the students in the experimental group produce essays that gain higher grades than those in the control group.

Marandi (2002) examined the use of meta-discourse in the introduction and discussion parts of 30 master theses written by Persian speakers and English speakers. She compared three kinds of text (texts by British English writers, texts by Persian Iranian writers, and text by English Iranian writers). He analyzed the first 1000 words in each introduction and section of the master theses to identify the extent and the subcategories of meta-discourse. The findings indicated that in introductions, the textual meta-discourse subtypes were applied considerably, but in the discussion sections, interpersonal meta-discourse subcategory were employed more. Furthermore, the results showed that the native speakers of Persian used logical and connectors more than the native speakers of English.

Hyland (2004) in his article called " Disciplinary interaction: Meta-discourse in L2 postgraduate writing" examines how advanced second language writers apply meta-discourse in various research genres. In this study, a corpus of 40 doctoral and masters' dissertations including four million words, written by Hong Kong students, were analyzed. 20 masters and 20 doctoral dissertations from each of the six academic discipline: electronic engineering, computer science, business studies, biology, applied linguistic and public administration. The meta-discourse distribution shows the importance of meta-discourse markers in student writing. The results indicate that writers used more interactive than interactional markers. He concluded that hedges and transitions were the most frequent devices followed by evidential and engagement markers.

Zarei and Mansoori (2011) examine the meta-discourse patterns in Persian and English languages within two disciplines (computer engineering and applied linguistics). The corpus was analyzed according to the model of Hyland and Tse (2004). The results indicate different use of meta-discourse patterns in two languages in disciple study. It was shown that Persian used more interactive resources than English. Moreover, Persian computer engineering applied more textual elements, whereas English language credited a reader responsible trend.

Firoozian, Khajavy, and Vahidnia (2012) examine the use of interactive and interactional meta-discourse devices in two fields, applied linguistics and engineering. The corpus was 8 research articles of engineering discipline and 8 articles of applied linguistics. The results indicate that in both fields, writers applied an interactive meta-discourse more than an interactional one. In addition, there were individual differences in interactive and interactional features, e.g. engineering writers employed more code glosses and endophoric markers, and less sequences and topicalisers than applied linguistic writers. Moreover, engineering writers applied more hedges and self-mentions, and less attitude markers and boosters that applied linguistics writers.

Khedri, Ebrahimi, and SweeHeng (2013) explored the interactional meta-discourse markers in the result and discussion part of academic research articles through four fields (English language, Teaching, Civil engineering, Biology, and Economics). In this paper, sixteen research article result and discussion parts (4 from each field) were selected from Leading Interactional Journals and analyzed. The findings indicated that there were not statistically considerable differences, but boosters between disciplines in the use of interactional meta-discourse markers.

Meta-discourse markers guide the reader within the text and make a way for the writer to interact or affect the reader. Appropriate use of meta-discourse markers raises the coherence or holistic meaning of the written prose. The $\mathrm{PhD}$ and Master dissertation are considered to be very important for the advanced university students. In spite of great importance of meta-discourse in dissertation, few researchers have examined master theses especially sub-disciplines of applied linguistics in search of meta-discourse markers. Therefore, it is necessary to 
study interactive and interactional meta-discourse markers in-accordance with Hyland (2005) in these MA theses to emphasize the importance of these markers in MA theses of English disciplines. This study aims to reveals the differences of these meta-discourse markers among three disciplines of English Translation, English Teaching and English Literature in conclusion section in MA theses. According to scope of study, these questions can be drawn:

Are there any significant differences between English Translation and English Literature disciplines in conclusion section of Master thesis in terms of using interactive and interactional meta-discourse markers?

$>\quad$ Are there any significant differences between English Literature, and English Teaching disciplines in conclusion section of Master thesis in terms of using interactive and interactional meta-discourse markers?

$>\quad$ Are there any significant differences between English Translation and English Teaching disciplines in conclusion section of Master thesis in terms of using interactive and interactional meta-discourse markers?

$>\quad$ Are there any significant differences among English Translation, English Teaching and English Literature disciplines in conclusion section of Master thesis in terms of using interactive and interactional meta-discourse markers?

\section{Methodology}

\subsection{Corpus}

The corpus of this study for first, second, and third question includes 30 Master Theses of English language disciplines (Translation, Teaching, Literature, each 10 Thesis). These Master Theses have similar structures but different contents. These Theses were selected randomly from library of Azad university of Najaf Abad, Azad university of Arak, and Isfahan University. The participants of this study includes the 30 MA students of Isfahan University, Azad university of Arak, and Azad university of Najaf Abad (10 students of English Literature were chosen from Azad university of Arak; 3 students of English Teaching were chosen from Azad university of Najaf Abad and other 7 students of English Teaching were chosen from Isfahan University; 10 students of English Translation were chosen from Isfahan university), because of inaccessibility of Translation theses in Azad university of Najaf Abad and Arak branch. Both male and female were selected randomly. The conclusion sections of these Theses were written and then stored in three folders of translation, literature, and teaching in computer. Their passages were read carefully and interactive and interactional meta-discourse markers were counted manually by researcher or other mater student or master who specializes in meta-discourse resources and analyzed statistically by SPSS software among Translation, Teaching, and Literature master Theses. Therefore, for this study inter-reliability was employed.

\subsection{Instrument}

As it was noted in previous sections in this chapter, an interpersonal model of Hyland (2005) was employed as an instrument to analyze interactive and interactional meta-discourse markers in conclusion sections of 30 Master Theses of English Translation, English Literature, and English Teaching to disclose the differences among these conclusion sections in using interactive and interactional meta-discourse markers. The model of Hyland (2005) is present in the earlier Table 1.

\subsection{Procedure}

In this study, in first, second, third, and fourth question, 30 Master Theses of English Language disciplines consisting Translation, Literature, and Teaching Theses ( from each 10 Theses) were selected randomly from 
Rezaei Zadeh, Z., Baharlooei, R., \& Simin, S.

library of Azad University of Najaf Abad, Azad University of Arak, and Isfahan University. The participants of this study includes the 30 MA students of Isfahan University, Azad university of Arak, and Azad university of Najaf Abad (10 students of English Literature were chosen from Azad university of Arak; 3 students of English Teaching were chosen from Azad university of Najaf Abad and other 7 students of English Teaching were chosen from Isfahan University; 10 students of English Translation were chosen from Isfahan university (because of inaccessibility of Translation theses in Azad university of Najaf Abad and Arak branch). Both male and female were selected randomly. The conclusion sections were written.

Then, these sections were typed and stored in 3 folders of translation, literature, and teaching. Conclusion sections of these Theses were read word by word carefully so as to find out the interactive and interactional meta-discourse markers frequency based on Hyland (2005). The markers were counted manually and functionally to ensure the validity of the research. All data were analyzed twice by researchers to prevent from any fault in counting the frequency of meta-discourse markers or evaluated by other Master student of English teaching or Master of English teaching who have similar knowledge regarding interactive and interactional meta-discourse markers based on Hyland (2005).Therefore, this study applied inter-reliability. Frequency of these meta-discourse markers were compared between Teaching and Translation Theses; Teaching and Literature Theses; and Translation and Literature Theses. The results were shown in tables.

\section{Data Analysis}

The conclusion sections of 30 master theses of English language disciplines (Teaching, Literature, and Translation) were selected randomly from library of Azad University of Najaf Abad, Azad University of Arak, and Isfahan University. These sections were written then stored in three folders of translation, literature, and teaching in computer. Afterwards, they were read word by word and carefully so as to count the interactive and interactional meta-discourse markers based on Hyland (2005) model manually. These conclusion sections were analyzed twice by researchers or other master student who have similar knowledge regarding interactive and interactional meta-discourse markers. Frequency of these meta-discourse markers were compared between Teaching and Translation Theses; Teaching and Literature Theses; and Translation and Literature Theses. In order to find out the differences among three disciplines of English Language Master Theses, chi-square was applied.

\section{Results}

In this section, the results of descriptive and referential analysis are presented. Firstly, frequency of interactive and interactional meta-discourse markers in each disciplines are shown in tables and described. Second, the analysis of differences between English Translation and English Teaching; English Translation and English Literature; English Teaching and English Literature are explained.

Descriptive Analysis of English Translation - In table 2, the frequency of interactive and interactional markers of English Translation is shown as follows:

Table 2

Descriptive Analysis of English Translation

\begin{tabular}{lcc}
\hline \multicolumn{1}{c}{ Interactive markers } & $f$ & $p$ \\
\hline Transitions & 172 & 63.23 \\
Frame & 25 & 9.19 \\
Endophoric & 26 & 9.55 \\
Evidentials & 26 & 9.55 \\
Code-glosses & 23 & 8.45 \\
\hline$n$ & 272 & 41.02 \\
\hline
\end{tabular}


Table 2 ... continued

Descriptive Analysis of English Translation

\begin{tabular}{lcc}
\hline \multicolumn{1}{c}{ Interactional markers } & $f$ & $p$ \\
\hline Boosters & 84 & 21.48 \\
Attitude & 138 & 35.29 \\
Self-mention & 3 & 0.76 \\
Hedges & 22 & 8.18 \\
Engagement & 134 & 32.27 \\
\hline$n$ & 391 & 58.97 \\
\hline$N$ & 663 & 100 \\
\hline
\end{tabular}

In this table, among Interactive Markers of English Translation, most percentage belongs to Transition with $63.23 \%$ and least percentage relates to code glosses with $8.45 \%$. Among Interactional Markers, most percentage belongs to Engagement markers with 34.27 and least percentage relates to self-mentions with 0.76 . In sum, it concludes that Interactional Markers with $58.97 \%$ are used more than Interactive Markers with $41.02 \%$.

Descriptive Analysis of English Teaching - In table 3, the frequency of interactive and interactional markers of English Teaching will be presented as follows:

Table 3

Descriptive Analysis of English Teaching

\begin{tabular}{lcc}
\hline \multicolumn{1}{c}{ Interactive markers } & $f$ & $p$ \\
\hline Transitions & 286 & 81.48 \\
Frame & 32 & 9.11 \\
Endophoric & 26 & 7.40 \\
Evidentials & 2 & 0 \\
Code-glosses & 5 & 1.42 \\
\hline$n \quad$ Interactional markers & 351 & 47.24 \\
\hline \multicolumn{1}{c}{ Boosters } & $f$ & $p$ \\
Attitude & 183 & 46.86 \\
Self-mention & 95 & 24.86 \\
Hedges & 13 & 3.31 \\
Engagement & 13 & 3.31 \\
\hline$n$ & 88 & 22.44 \\
\hline$N$ & 392 & 52.75 \\
\hline
\end{tabular}

As it is indicated, among Interactive Markers of English Teaching, most percentage belongs to Transition with $81.48 \%$ and least percentage relates to Evidential with $0.56 \%$. Among Interactional Markers, most percentage belongs to boosters with $46.68 \%$ and least percentage relates to Self-mentions and Hedges with $3.31 \%$. Generally, Interactional Markers with 52.75 were applied more than Interactive ones with 47.24.

Descriptive Analysis of English Literature - In table 4, the frequency of interactive and interactional markers of English Literature are illustrated as follows:

Table 4

Descriptive Analysis of English Literature

\begin{tabular}{lcc}
\hline \multicolumn{1}{c}{ Interactive markers } & $f$ & $p$ \\
\hline Transitions & 680 & 77.18 \\
Frame & 66 & 7.49 \\
Endophoric & 83 & 9.42 \\
Evidentials & 16 & 1.81 \\
Code-glosses & 36 & 4.08 \\
\hline$n$ & 881 & 41.46 \\
\hline
\end{tabular}


Rezaei Zadeh, Z., Baharlooei, R., \& Simin, S.

Table 4 ... continued

Descriptive Analysis of English Literature

\begin{tabular}{lcc}
\hline \multicolumn{1}{c}{ Interactional markers } & $f$ & $p$ \\
\hline Boosters & 221 & 17.88 \\
Attitude & 443 & 35.84 \\
Self-mention & 81 & 4.12 \\
Hedges & 50 & 4.04 \\
Engagement & 471 & 38.1 \\
\hline$n$ & 1236 & 58.38 \\
\hline$N$ & 2117 & 100 \\
\hline
\end{tabular}

Concerning the frequency and percentage of English Literature, Transition with $77.18 \%$ has the most percentage and Evidential with $1.81 \%$ is least percentage. In interactional Markers, Engagement Markers with $38 \%$ has the most percentage and hedges with $4.04 \%$ have the least percentage. According to these results, Interactional Markers are employed more than Interactive ones.

\section{Referential Analysis of Research Questions - Research Question 1}

The first research question addressed the differences between English Translation and English Literature disciplines in conclusion section of MA theses in terms of using interactive and interactional meta-discourse markers. In order to answer the first research question, chi-square test was applied. In table 5, the chi-square results are shown as follows.

\section{Table 5}

Chi-square Test (Research Question 1)

\begin{tabular}{lccc}
\hline \multicolumn{1}{c}{ Statistics } & $X^{2}$ & $d f$ & Sig.(2-sided) \\
\hline Pearson Chi-square & 0.72 & 1 & 0.788 \\
Continuity correction & 0.50 & 1 & 0.823 \\
Likelihood Ratio & 0.72 & 1 & 0.288 \\
Linear-by Linear Association & 7.005 & 1 & 0.008 \\
$\mathrm{~N}$ & 2780 & & \\
\hline
\end{tabular}

The results of chi-square Test in Table 5 reveals that significance level is $0.78>0.05$ which means there are not any significant differences between English Translation, English Literature disciplines in conclusion sections of master theses in terms of using Interactive and Interactional meta-discourse Markers. Thus, the hypothesis one is confirmed.

Research Question 2 - The second research question tried to determine if there are any significant differences between English Literature, and English Teaching disciplines in conclusion section of master theses in terms of using Interactive and Interactional meta-discourse Markers. In order to examine the second research question, chi-square test was applied. In table 6 , the results of chi-square test are represented.

\section{Table 6}

Referential Analysis (Research Question 2)

\begin{tabular}{lccc}
\hline \multicolumn{1}{c}{ Statistics } & $X^{2}$ & $d f$ & Sig.(2-sided) \\
\hline Pearson Chi-square & 2.098 & 1 & 0.008 \\
Continuity correction & 6.870 & 1 & 0.009 \\
Likelihood Ratio & 7.088 & 1 & 0.008 \\
Linear-by Linear Association & 7.005 & 1 & 0.008 \\
$\mathrm{~N}$ & 2860 & & \\
\hline
\end{tabular}

The results illustrated in Table 6 , indicates that the significant level is $0.008<0.05$. Based on the results obtained in Table 6, there are any significant differences between English Literature, and English Teaching disciplines in conclusion section of master thesis in terms of using Interactive and Interactional meta-discourse 
Markers. So, the second hypothesis is rejected.

Research Question 3 - The third research question addressed whether there are any significant differences between English Translation and English Teaching disciplines in conclusion section of master thesis in terms of using Interactive and Interactional meta-discourse Markers. Chi-square test was applied to assess the following differences between English Translation and English Teaching disciplines in conclusion section of master thesis in terms of using Interactive and Interactional meta-discourse Markers. In the following Table 7, chi-square test of third hypothesis is presented in the following section.

\section{Table 7}

Referential Analysis (Research Question 3)

\begin{tabular}{lccc}
\hline \multicolumn{1}{c}{ Statistics } & $X^{2}$ & $d f$ & Sig.(2-sided) \\
\hline Pearson Chi-square & 5.485 & 1 & 0.019 \\
Continuity correction & 5.236 & 1 & 0.022 \\
Likelihood Ratio & 5.492 & 1 & 0.019 \\
Linear-by Linear Association & 5.481 & 1 & 0.019 \\
$\mathrm{~N}$ & 1406 & & \\
\hline
\end{tabular}

The results illustrated in Table 7 shows that significance level is $0.019<0.05$ which indicates that there are significant differences between English Literature, and English Teaching disciplines in conclusion section of master theses in terms of using Interactive and Interactional meta-discourse Markers. Consequently, the third hypothesis is rejected.

Research Question 4 - The forth research question tried to explore if there are any significant differences among English Translation, English Teaching and English Literature disciplines in conclusion section of master thesis in terms of using Interactive and Interactional meta-discourse Markers. In order to examine the differences among English Translation, English Teaching and English Literature disciplines in terms of applying Interactive and Interactional meta-discourse Markers, chi-square Test was considered and will be presented as follows.

\section{Table 8}

Referential Analysis (Research Question 4)

\begin{tabular}{lccc}
\hline \multicolumn{1}{c}{ Statistics } & $X^{2}$ & $d f$ & Sig.(2-sided) \\
\hline Pearson Chi-square & 8.039 & 1 & 0.018 \\
Likelihood Ratio & 7.997 & 1 & 0.018 \\
Linear-by Linear Association & 5.853 & 1 & 0.016 \\
N & 3523 & & \\
\hline
\end{tabular}

The findings of chi-square Test, illustrated in Table 8 shows that significance level is $0.018<0.05$. Regarding these findings, there are not any significant differences among English Translation, English Teaching and English Literature disciplines in conclusion section of master thesis in terms of using Interactive and Interactional meta-discourse Markers. Therefore, hypothesis four is also rejected.

\section{Discussion}

With regard to the research questions, conclusions were made that there are not any significant differences between English Translation, English Literature disciplines in terms of using Interactive and Interactional meta-discourse Markers. So the first hypothesis was confirmed. But, there are significant differences between English Literature, and English Teaching and between Translation and English Teaching disciplines and among these three disciplines in conclusion sections in terms of using Interactive and Interactional meta-discourse Markers. Thus, second, third and fourth hypotheses are rejected.

Concerning the descriptive statistics of research questions, the findings indicates that, Interactional Markers among these disciplines were employed more than Interactive ones. Interactional Markers were used as most 
Rezaei Zadeh, Z., Baharlooei, R., \& Simin, S.

proportion in English Translation with 58.97\% comparing to English Teaching with 52.75\% and English Literature with 58.38\%. Among Interactive Markers, Transitions are applied more than other Interactive Markers such as Frame Markers, Endophoric Markers, Evidential and Code glosses. Among interactional markers, in English Translation, Attitude Markers with 35.29\%, in English Teaching, Boosters with $46.68 \%$ and in English Literature, Engagement Markers with $38.1 \%$ were applied as most proportion.

The findings of this study confirmed the results reported by Hyland and Tse (2004); Kuhi, Yavari, and Sorayyaei (2012); Tavakoli, Amirian, and Moslemi (2012); while, run counter to Firoozian, Khajavy, and Vahidnia (2012); Zarei and Mansouri (2011); Faghih and Rahimpour (2009). Firoozian, Khajavy, and Vahidnia (2012), found that in research articles written by Iranian applied linguistic and engineering writers, interactive and interactional features were used in both group, but writers used an interactive meta-discourse markers more than interactional ones. Besides, Zarei and Mansoori (2011) concluded the frequent usage of interactive meta-discourse markers in humanity fields. The results obtained by Faghih and Rahimpour (2009) indicated that interactive factors were used significantly more than interactional ones in discussion sections of applied linguistic research articles.

In line with findings of this paper, Hyland and Tse (2004) found that interactional meta-discourse markers as the most frequent markers (hedges, transitions, and engagement markers). They also suggested that the most usage of meta-discourse was in applied linguistics and the least usage of meta-discourse in electronic discipline. Hyland (2005) believes that interactional resources help writers making their inputs clear and engaging their readers in the text. In another study by Kuhi, Yavari, and Sorayyaei (2012), it was explored the heavier use of interactional devices in discussion and conclusion sections of articles. They suggested that writers are aware of the subjective nature of discussion and conclusion sections and these sections are more explicitly interpersonal and evaluative.

\section{Conclusion and Implications}

Hyland (2004), states "meta-discourse is particularly important at advanced levels of academic writing, as it is represents writers attempts to presents, and negotiate propositional information in way that are meaningful, and appropriate to a particular disciplinary community. Meta-discourse provides a link between texts and disciplinary cultures, helping to define the rhetorical context by revealing some of the expectations, and understandings of the audience for whom a text was written (p. 136)". Based on the results reported and the discussion conducted in the previous sections, the following conclusions can be drawn.

$>$ Concerning the distribution of interactive and interactional meta-discourse markers in English Translation, English Teaching, and, English Literature M.A Theses, in all disciplines, interactional markers were employed more than interactive ones. But, interactional markers were used as most proportion in English Translation with $58.97 \%$ comparing to English Literature with $58.38 \%$ and English Teaching with $52.75 \%$.

$>\quad$ Considering the differences between and among English Translation, English Teaching, and, English Literature, there are significant differences between there are significant differences between English Literature, and English Teaching and between Translation and English Teaching disciplines in conclusion sections of MA theses and among all disciplines. But there are not any significant differences between English Translation, English Literature disciplines.

$>\quad$ Based on descriptive analysis of gender-based study of interactive and interactional meta-discourse markers in conclusion sections of English Translation, English Teaching, and, English Literature M.A Theses, in English Translation, both male and female writers applied more interactional markers with $60.66 \%$ comparing to male writers with $41.37 \%$. In English Teaching, both male and female writers employed more Interactional Markers more than interactive ones. While, female writers used Interactional Markers with 51.18 more than male writers ones with 51.7\%. In English Literature, both 
Interactive and interactional meta-discourse markers in conclusion sections of English master theses

male and female writers employed Interactional Markers more than interactive ones. Nevertheless, male writers used Interactional Markers with $60.65 \%$ more than female writers ones with 55.15\%.

$>$ Regarding the referential analysis, it can be concluded that, there are significant differences between male and female writers concerning use of Interactive and Interactional meta-discourse Markers in English Translation, and English Literature M.A Theses. While there are not any significant differences between male and female writers regarding use of these meta-discourse Markers in English Teaching.

The results of the study can be beneficial for postgraduate students of Applied Linguistics (English Translation, and English Literature, and English Teaching).It is necessary to make learners aware of these markers and their functions in the text, for example, language texts from prominent websites can be applied to emphasize their appropriate use. Students must pay attention to Interactive and Interactional meta-discourse Markers in Master and Ph.D. Thesis. In addition, the findings of this study would be considerably important for supervisors and advisors in guiding and giving advice students in Applied Linguistics. Professors can encourage students to apply these meta-discourse markers in Master and Ph.D. Thesis appropriately. It is crucial for instructors to teach these meta-discourse markers especially to master theses writers. The findings of this research would help to keep masters and professors aware of the rhetorical differences among these sub-disciplines of applied linguistics.

Simin and Tavangar (2009), in relevance to meta-discourse awareness, present some techniques for improving the writing of EFL/ESL learners. One technique can be encourage and assign them to write to a real audience in the target culture. It makes writing in English more interesting, challenging and educational for EFL learners. Another method should be done by teachers. They can give students an understanding of their capacity to write, motivation, self-confidence and instruction in knowledge about the appropriate use of meta-discourse as well as other rhetorical strategies. To sum up, as noted by Simin et al. (2014), by explicit instruction and raising awareness, teachers can improve the writing skill of EFL learners. Therefore, the findings of this study support the need for instruction of meta-discourse markers in EFL classrooms in order to enhance the learners' writing performance.

\section{References}

Adel, A. (2006). Meta-discourse in L1 and L2 English. Philadelphia: John Benjamins. http://dx.doi.org/10.1075/scl.24

Amiri, M. (2001). The effect of meta-discourse consciousness raising on the improvement of Iranian EFL learners writing skill. A thesis submitted in partial fulfillment of the requirement for the degree M.A. Iran University of Science and Technology. Retrieved from http://www.database.irandoc.ac.ir

Bunton, D. (1999). The use of higher level metatext in PhD theses. English for Specific Purpose, 18, 41-56. http://dx.doi.org/10.1016/S0889-4906(98)00022-2

Crismore, A., \& Farnsworth, R. (1990). Meta-discourse in popular and professional science discourse. In W. Nash (Ed.), The writing scholar: Studies in academic discourse sage (pp.118-136). Newbury Park: London.

Crismore, A., Markkanen, R., \& Steffensen, M. (1993). Meta-discourse in persuasive writing: A study of texts written by American and Finnish university students. Written Communication, 10(1), 39-71. http://dx.doi.org/10.1177/0741088393010001002

Enkvist, N. (1975). Basic concepts of text linguistics. Helsinki: Gaudeamus, Forceville, Charles.

Faghih, E., \& Rahimpour, S. (2009). Contrastive rhetoric of English and Persian written text: Meta-discourse in applied linguistic research articles. Rice Working Papers in Linguistic, 1, 92-107.

Firoozian, P. A., khajavy, G. H., \& Vahidnia, F. (2012). A contrastive study of meta-discourse elements in research articles written by Iranian applied linguistics and engineering Writers in English. English Linguistics Research, 1(1), 88-96. 
Rezaei Zadeh, Z., Baharlooei, R., \& Simin, S.

Halliday, M. A. K. (1978). Language as social semiotic: The social interpretation of language and meaning. Baltimore: University Park Press.

Hyland, K. (1998). Persuasion and context: The pragmatics of academic meta-discourse. Journal of Pragmatics, 30, 437-455. http://dx.doi.org/10.1016/S0378-2166(98)00009-5

Hyland, K. (2000). Disciplinary discourses: Social interaction in academic writing. London: Pearson.

Hyland, K. (2004). Disciplinary interactions: Meta-discourse in L2 postgraduate writing. Journal of Second Language Writing, 13, 133-151. http://dx.doi.org/10.1016/j.jslw.2004.02.001

Hyland, K. (2005). Meta-discourse: Exploring interaction in writing. London: Continuum.

Hyland, K., \& Tse, P. (2004). Meta-discourse in academic writing: A reappraisal. Applied Linguistics, 25(2), 156-177. http://dx.doi.org/10.1093/applin/25.2.156

Intraprawat, P., \& Steffensen, M. S. (1995). The use of meta-discourse in good and poor ESL essays. Journal of Second Language Writing, 413, 253-272. http://dx.doi.org/10.1016/1060-3743(95)90012-8

Khedri, M., SweeHeng, C., \& Ebrahimi, F. (2013). An exploration of interactive meta-discourse markers in academic research article abstracts in two disciplines. Discourse Studies, 15, 319--331. http://dx.doi.org/10.1177/1461445613480588

Kuhi, D., Yavari, M., \& Sorayyaei, A. (2012). Meta-discourse in applied linguistics research articles: A cross-sectional survey, Iranian EFL Journal, 3(11), 405-414.

Marandi, S. (2002). A contrastive EAP rhetoric: Meta-discourse in Persian vs. English. Doctoral dissertation, Tehran University, Iran.

Mauranen, A. (1993). Contrastive ESP rhetoric: Meta-text in Finnish-English economic texts. Journal of English for Specific Purposes, 13(2), 149-170.

Simin, S., \& Tavangar, M. (2009). Meta-discourse knowledge and use in Iranian EFL writing. The Asian International Journal of Foreign Language Teaching \& Research, 11(1), 230-255.

Thompson, G. (2001). Interaction in academic writing: Learning to argue with the reader. Journal of Applied Linguistics, 22(1), 58-78. http://dx.doi.org/10.1093/applin/22.1.58

Valero-Garces, C. (1996). Contrastive ESP rhetoric: Meta-text in Spanish-English economic texts. Journal of English for Specific Purposes, 15(4), 279-294. http://dx.doi.org/10.1016/S0889-4906(96)00013-0

VandeKopple, W. J. (1985). Some explanatory discourse on meta-discourse. College Composition and Communication, 36, 63-94.

Webster New Collegiate dictionary. (2014). An encyclopedia Britannica company. Retrieved from http://www.merriam-webster.com

William, J. (1981). Style: Ten lessons in clarity and grace ( $3^{\text {rd }}$ ed.). Boston: Scott Foresman.

William, J. (1989). Style: Ten lessons in clarity and grace ( $5^{\text {th }}$ ed.). Boston: Scott Foresman.

Zarei, G. R., \& Mansoori, S. (2011). A Contrastive study on meta-discourse elements used in humanities vs. non humanities across Persian and English. English Language Teaching, 4(1), 42-50.

http://dx.doi.org/10.5539/elt.v4n1p42 